\title{
The Effects of Small Dams on Agriculture and Groundwater Development: A Case Study of the Tendahah Dam, Asir Region, Saudi Arabia
}

\author{
Moshabab M. Alhader \\ King Saud University, Riyadh, Kingdom of Saudi Arabia \\ Email: Mushabab_2@yahoo.com
}

How to cite this paper: Alhader, M. M (2020). The Effects of Small Dams on Agriculture and Groundwater Development: A Case Study of the Tendahah Dam, Asir Region, Saudi Arabia. Journal of Geoscience and Environment Protection, 8, 150-161.

https://doi.org/10.4236/gep.2020.811009

Received: October 12, 2020

Accepted: November 17, 2020

Published: November 20, 2020

Copyright $\odot 2020$ by author(s) and Scientific Research Publishing Inc. This work is licensed under the Creative Commons Attribution International License (CC BY 4.0).

http://creativecommons.org/licenses/by/4.0/

\begin{abstract}
During this research, it was verified that small dams play an important role in groundwater sustainability and agriculture. The main objective of this study was to assess the impacts of the Wadi Tendahah dam on groundwater and agriculture. Proper planning and management of small dams may improve sustainable agriculture in the Tendahah region. The study also found that the construction of the Tendahah Valley Dam on an impermeable rock layer had a major role in the lack of groundwater recharge, especially in the dry seasons, and this, in turn, affected agriculture in its study area. Given the positive and negative impacts of the Tendahah Valley Dam or similar, the appropriate place for the construction and maintenance of small dams should be chosen periodically.
\end{abstract}

\section{Keywords}

Small Dams, Groundwater, Tendahah Valley Dam, Evaporation, Agriculture

\section{Introduction}

There is no specific date for the beginning of the construction of dams, but it is believed that they date back more than 5000 years, but most of the dams in the world came after World War II with the aim of economic development (Zarfl et al., 2014). Dams are among the most harmful human activities in permanent river basins. Or dry, which modifies the geography of watersheds. The reservoirs may look a lot like natural lakes. However, the operating system defined by the purpose of the reservoirs may significantly alter their physicochemical character and biological responses. Reservoirs undergo major changes in water quality 
during the first stages of their formation until a new environmental balance is achieved, followed by some kind of stability, but the occurrence of flooding, operational activities, or other impacts may create new disturbances (Straskraba et al., 1993; Rueda et al., 2006). The scale and extent of construction of dams and associated water diversions, exploitation of aquifers, channeling of waterways, and water transport between basins in the world today is so great that these hydrological changes have environmental impacts at the global level (Rosenberg et al., 2000). Dams differ in terms of their size, height, and structural shape, as well as in terms of the purpose of their construction, and the passion for the most prominent objectives of their construction: 1) drinking and industrial water supply and cooling 2) hydropower generation 3) agricultural irrigation 4) river regulation and flood control 5) transportation 6) recreation and fisheries ( $\mathrm{Na}$ et al., 2014). Results of a case study (Jaafar, 2014) on more than eighty proposed dams indicate that assessment of reliability, annualized cost/demand satisfied, and yield is crucial before investment decision making in arid areas. Irrigation demand is the major influencing parameter on the yield and reliability of recharge dams. He stated (Soares et al., 2019) that the projected increase in consumption/habitat and the decrease in annual rainfall have become a reality in the next two decades. This study proposes a move towards dual water management based on surface water stored in small dams and groundwater. He indicated (Çelik, 2018). The impact of dams on groundwater through the lower basin and their role in providing agricultural irrigation and drinking water in water collection basins (Çelik, 2018). The role of small dams and associated reservoirs has notable effects on soil and water dynamics in prairie streams (Ashraf et al., 2007; Ejaz et al., 2016). After the construction of dams and irrigation canals, the intensity of crops and the productivity of crops increased, due to the availability of irrigation water, there has been a shift in the cropping pattern from wheat and forage crops to vegetable crops. The Kingdom of Saudi Arabia is an arid region with limited rainfall and a gradient of temperature, as it has fewer surface water bodies, which are only in the form of dams, and this increases the pressure on the limited number of non-renewable groundwater reservoirs (Abushandi, 2016). In light of the increasing issues of water scarcity in the Kingdom and the face of decreasing amounts of annual precipitation, and its increasing water needs every day, we find that small dams play an important role in the sustainability of groundwater and agriculture. The Tendahah Dam contributes significantly to the region's economy; the population in the study area depends on groundwater that is recharged from the dam lake to irrigate their farms and produce crops. Also, these dams are not without environmental impacts in the event of neglecting their good and proper management, which will negatively affect the groundwater or the crops, especially those far from the dam basin. Therefore, this study aims to estimate the impact of small dams (Tendahah Dam as a case study) on agriculture and groundwater development in an arid climate, and the implications of building dams on farmers' economies. 


\section{Study Area}

The Tendahah Dam is in the Asir region of the Kingdom of Saudi Arabia within the southwestern region in the upper Tendahah Valley. It was built in the year $1404 \mathrm{AH}$, and it is a concrete dam that aims to provide drinking water and farmers who depend mainly on agriculture downstream. It is about $120 \mathrm{~m}$ in length and $24.5 \mathrm{~m}$ in total height. The total water storage capacity is $4.2 \mathrm{million} \cdot \mathrm{m}^{3}$. According to Google Maps, the Tendahah Dam is located at latitude $18^{\circ} 21^{\prime} 55.5^{\prime \prime} \mathrm{N}$ and longitude $42^{\circ} 50^{\prime} 08.4^{\prime \prime} \mathrm{E}$ (Figure 1 and Figure 2).

\section{Research Methodology}

\subsection{Field Visit}

A survey of the primary data collected from the study area, the dam, the type of crops and cropping patterns, the type of soil and climate, and the groundwater, as it was collected through field visits and discussions.

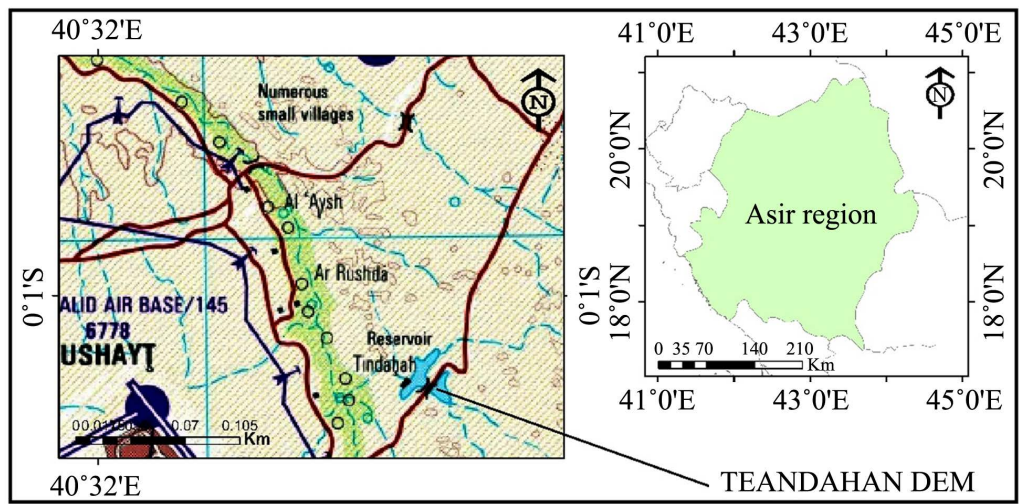

Figure 1. Site of the Tendahah Dam. Source researcher based on http://legacy.lib.utexas.edu/maps/jog/saudi_arabia/.

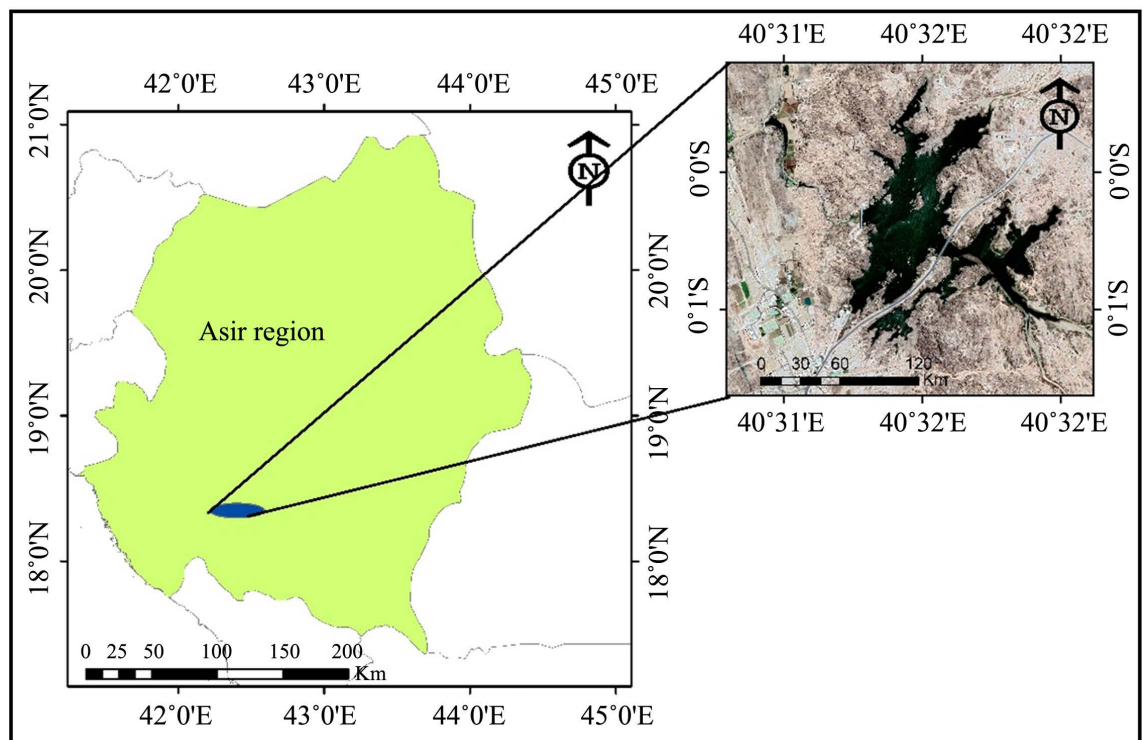

Figure 2. Lake wadi Tendahah dam. Source researcher. 


\subsection{Data}

The dam data was obtained from the Ministry of Environment, Water, and Agriculture data. Climatic data were also obtained from the Meteorology and Environment Protection Authority and the Ministry of Environment, Water, and Agriculture for the period 1984-2018.

\subsection{Questionnaire}

A closed questionnaire was prepared for farmers in the Wadi Tandha basin from the dam area to the end of the basin area, including the owners of agricultural holdings, as it included a different set of questions regarding the charging of wells with groundwater, types of crops, irrigation method, and depth of groundwater.

\subsection{Data Analysis}

The data obtained from the field survey or questionnaires were theoretically analyzed. GIS software was also used to produce maps for the region.

\section{Results}

\subsection{Watersheds of the Tandha Valley Dam}

The Tandha Dam was built in 1984, on a high site at the top of the Tandha Valley, and the main purpose of its construction was to support the army position stationed near it. The Tendahah Valley is one of the most famous valleys in the Asir region and one of the most important tributaries of the Bisha Valley, and it originates from the Hijaz Mountains near the city of Sarat Abidah and meets some of the valleys and reefs that flow into it and passes through the center of Tadha until it flows into the Bisha Valley near Wadi Ibn Hashbal (Figure 3).

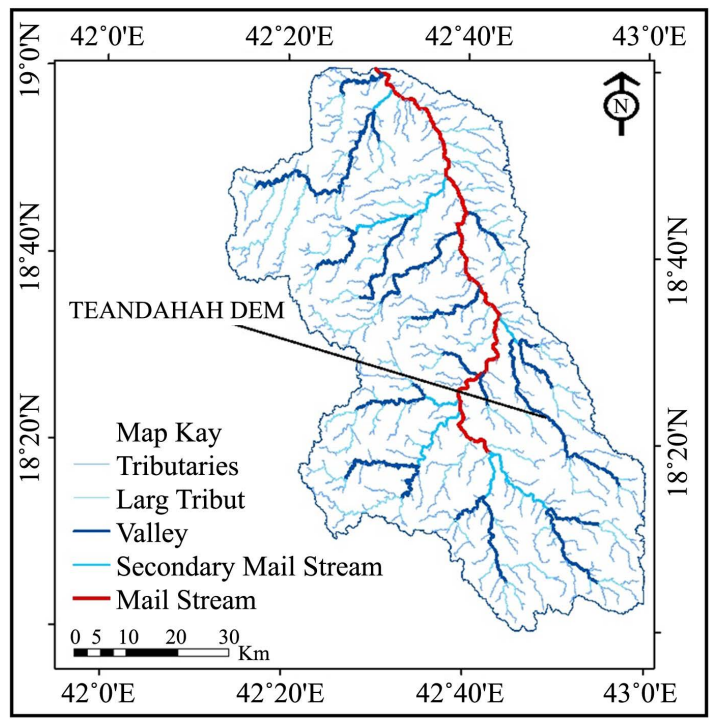

Figure 3. Wadi Tendahah stream with the watershed in eastern Asir basins. Source Researcher. 


\subsection{Geology and Topography of Wadi Tendhah}

Tendhah is located within the Asir region, which is one of the regions of the Arabian Shield, whose rocks consist of a sequence of igneous and metamorphic rocks belonging to the Late Proterozoic period, and the topographical diversity of the region varies. The most prominent rocks that represent tundra are amphibolite schist, mica schist, granite, and incisors. The quadruple valley sediments cover the depressions and lowlands along the valley. These sediments are formed as a result of weather factors and the disintegration of rocks near each valley, and they are unconsolidated sediments consisting of silt, sand, gravel, and occasional rocks (Ibnlaboun, 2019). The change in elevation along the main channel starting from the dam site downstream is used extensively for imaging surface water and endpoint depending on wet (high), normal (medium), and dry (low) seasons. The study area begins to gradually decrease as we move away from the dam area, and on both sides of the valley, many agricultural fields depend on wells for irrigation. The height of the study area is about $2407 \mathrm{~m}$ above sea level (Figure 4).

\subsection{Soils}

It is necessary to know the types of soil to be familiar with the different sizes of grains, to know the filtration potential, and their suitability for cultivation. generally; The soil consists of sand mixed with silt at depths between $3.5 \mathrm{~m}$ and $10.50 \mathrm{~m}$. It has a brown color with moderate to high density, in addition to a sandy brown loam layer with poor granulation, and moderate to very dense content, followed at the bottom by the granodiorite rock, a type of schist (Thobaity, 2009) (Figure 5).

\subsection{Rainfall Characteristics}

The amount of rain falling over the study area varies from year to year, due to its being a semi-arid region. The average annual precipitation is about $170-400 \mathrm{~mm}$,

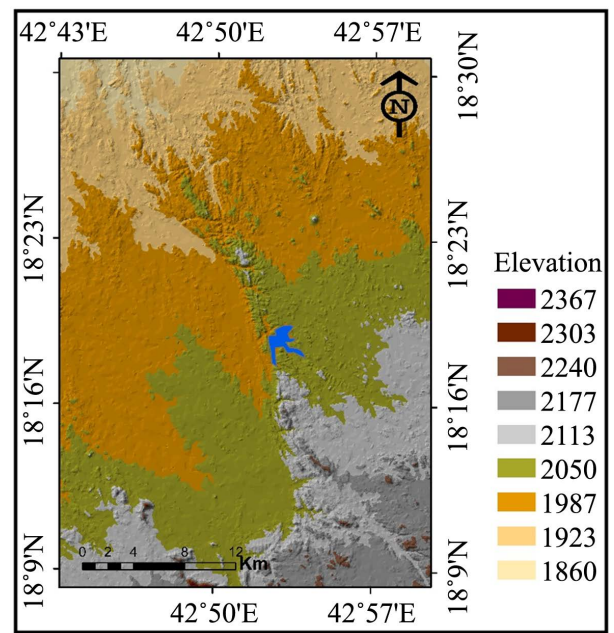

Figure 4. Topography of the study area. 


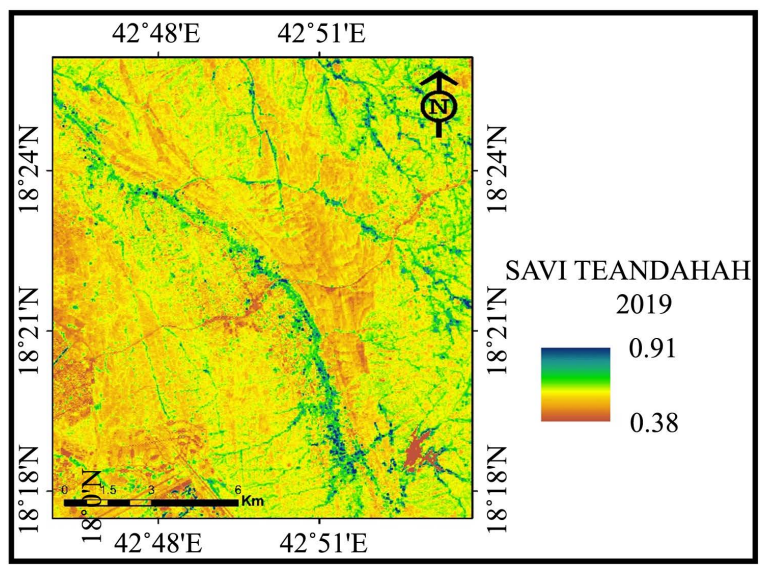

Figure 5. Index of adjacent soil vegetation (SAVI).

and this amount may decrease in some years to $15.7 \mathrm{~mm}$, (Met Office) (Table 1). Most of the region's rain falls in the late winter and spring, especially April and May, as it falls in the summer, but in smaller quantities than the previous one. Due to the seasonal pattern of rainfall, erosion and sediment yield follow a similar pattern, with the most valuable period of erosion and sediment yield being the first part of the wet season when rainfall is high but vegetation is not growing sufficiently to protect the surface (Figure 6). The slope of the surface and the strength of surface runoff during high precipitation increase erosion, transportation and increase the amounts of sedimentation in the dam basin.

\subsection{Groundwater Level for the Study Area}

Groundwater recharge depends on precipitation and storage in the dam lake. Rainy days contribute to the rise in groundwater levels. It is noticeable that the dam harms recharging groundwater in the areas surrounding the dam site, and the impact increases when we move away from the dam lake. Low groundwater levels are due to poor percolation, and the location of many wells at a distance from the dam lake. The location of the dam on igneous rocks, which constitute an insulating layer, was weakened by weak filtration, and over time, a layer of fine sand was formed over it, which worked to close the passages between these rocks, which reduced the utilization of groundwater from the water of the dam lake.

\subsection{Evaporation}

Lake Wadi Tendahah Dam is subject to evaporation and loss due to the increase in the kinetic energy of particles due to high temperatures, especially in the summer season. Table 2 shows the evaporation values in Lake Wadi Tendahah. It is noticed from the table that annual evaporation is very high, and this is a negative factor for dam siltation.

\subsection{Source of Irrigation}

Wadi Tendahah is the main source for cultivating fields in the region, and the 


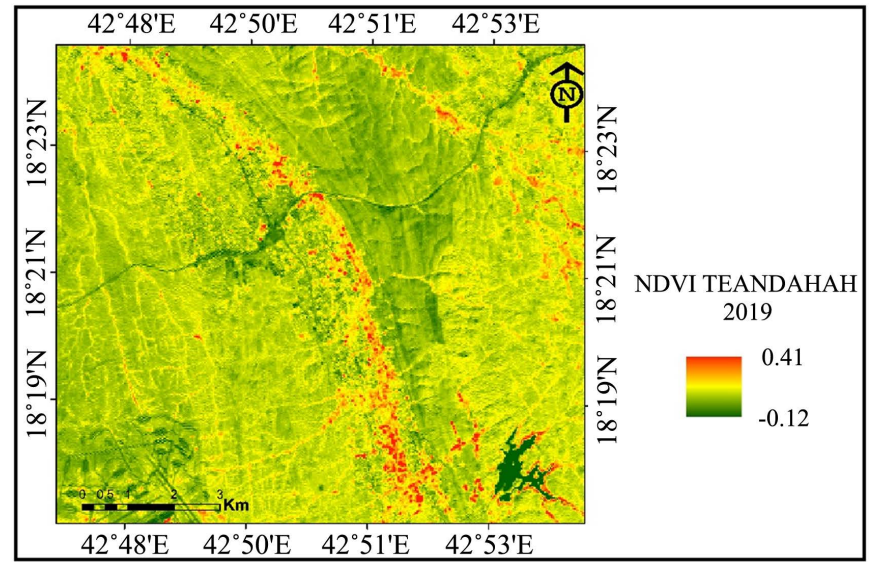

Figure 6. (NDVI) vegetation index for the study area.

Table 1. Annual precipitation amounts $(\mathrm{mm})$ in the Tendahah region for the period from 1984-2018.

\begin{tabular}{rrrrrrrrrrr}
\hline Year & 1984 & 1985 & 1986 & 1987 & 1988 & 1989 & 1990 & 1991 & 1992 & 1993 \\
\hline Precip & 83.4 & 227.1 & 122.9 & 230.7 & 151 & 242 & 268.1 & 191.5 & 338.3 & 250.7 \\
Year & 1994 & 1995 & 1996 & 1997 & 1998 & 1999 & 2000 & 2001 & 2002 & 2003 \\
Precip & 149.4 & 178.7 & 235.1 & 358.3 & 277.1 & 141.4 & 120.3 & 217 & 111.5 & 132.2 \\
Year & 2004 & 2005 & 2006 & 2007 & 2008 & 2009 & 2010 & 2011 & 2012 & 2013 \\
Precip & 238.5 & 144.5 & 196.2 & 211.3 & 98.8 & 34.9 & 269.3 & 144.5 & 90.9 & 112.7 \\
Year & 2014 & 2015 & 2016 & 2017 & 2018 & & & & & \\
Precip & 54.35 & 15.99 & 400.55 & 4.82 & 92.46 & & & & & \\
\hline
\end{tabular}

Table 2. Monthly evaporation rates ( $\mathrm{mm})$.

\begin{tabular}{ccccccccccccc}
\hline Month & Jan & Feb & Mar & Apr & May & Jun & Jul & Aug & Sep & Oct & Nov & Dec \\
\hline & 140.4 & 136 & 195 & 199 & 251 & 301 & 283 & 242.1 & 265 & 232.8 & 173.1 & 144.8 \\
Mean & 4.53 & 4.69 & 6.29 & 6.63 & 8.09 & 10.03 & 9.13 & 7.81 & 8.83 & 7.51 & 5.77 & 4.67 \\
St. Dev & 1.11 & 0.85 & 0.68 & 1.06 & 0.87 & 1.04 & 0.79 & 1.21 & 1.18 & 0.61 & 0.34 & 0.93 \\
\hline
\end{tabular}

Source: The researcher is based on data of the Ministry of Environment, Water and Agriculture.

valley water is relied upon to feed and recharge the wells with groundwater, but when the Wadi Tendahah dam was established, the groundwater level in the wells decreased. In the field survey, farmers mentioned that they abandoned their farms as a result of the wells drying out of the water, while others mentioned that they depend on the reefs that supply them with water, such as the people of Sala, Shuaib Al-Saq, Wadi Al-Feed, and others, which help in recharging the groundwater. $100 \%$ of those surveyed and questionnaires agreed that the construction of the dam and the failure to open its gates in dry seasons does not feed the ground wells and negatively affected agriculture. The suffering increases for farmers the further we move from the dam lake. This is a negative indication of the planning for the construction of the dam. The Tendahah Valley Dam 
plays a negative role in the sustainability of agricultural activities in the study area and is a very negative sign for food, agriculture, and the economy.

\subsection{Agricultural Crops}

There are many agricultural fields in the Wadi Tendahah basin concerned with the cultivation of vegetables of all kinds, as well as leaves, and the population is interested in cultivating orchards of pomegranates, figs, and grapes, and others grow some types of grains, and it is one of the largest markets in the region in supplying agricultural products to the market the local. During the field survey and questionnaire forms, farmers stated that they suffer as a result of building the dam in drought seasons in particular, which makes them lose the possibility of agriculture, affects their income, and negatively affects their social life. More than $90 \%$ of the study population depends on traditional irrigation (flood irrigation), especially in growing vegetables and grains, while nearly $8 \%$ use the drip irrigation system for fruit crops and $2 \%$ use pivot irrigation. The traditional irrigation method increases water losses due to leakage, evaporation, and poor irrigation methods.

\subsection{Analysis of the Questionnaire Forms}

The questionnaire forms were presented during the field survey of the farmers in the Wadi Tendahah basin to find out their polls and opinions on the impact of the Wadi Tendahah Dam on agriculture, and on groundwater levels in the Tendahah region. From near to the dam and up to more than $16 \mathrm{~km}$, those included in the research agreed that water levels decrease in dry seasons, and there is no recharge of groundwater, as $73 \%$ believe that their wells do not benefit from recharge. While neighboring people see a dam; their wells do not suffer from drought or low levels, as a result of water seeping through cracks and mouth openings into the valley, but it does not exceed $1.5 \mathrm{~km}$ from the dam. While $58 \%$ of them stated that the dam affected them directly or indirectly. While $36 \%$ see that there is a positive impact of the dam, especially those close to the lake, while $50 \%$ see that the positive impact of the dam does not exceed $20 \%-40 \%$. Some have also mentioned that they suffer from good owners selling water and filling up tanks, causing the groundwater to deplete. Regarding the possibility of removing the doors of the dam, $85 \%$ believe that this is one of the best solutions, especially in dry seasons, when the doors are allowed to be opened in a way that enables farmers to plant well, and wells are allowed to recharge again.

\subsection{Socio-Economic Impacts}

The construction of the Tendahah Dam showed negative social and economic impacts based on the opinions of the farmers during the field survey. The farmers mentioned that the construction of the dam affected the water table and the fertility of the soil, and this affected the farmers' financial situation, especially the further away from the dam lake. Indeed, many farmers abandoned their 
farms more than ten years ago due to the drought. Through a comparison between the satellite visuals for the year $2000 \mathrm{AD}$ and the year $2019 \mathrm{AD}$, to study land use, we notice that the agricultural fields are shrinking, especially the further we move from the dam lake (Figure 7(a) and Figure 7(b)).

\subsection{Environmental Impacts}

The environmental consequences of dams are many and varied, and include direct impacts on the biological, chemical, and physical characteristics of the aquatic environment behind the dam. The dam also traps sediments, which are necessary to maintain the physical processes and habitats at the dam's end, fertile flood plains, and wetlands (McCully, 1996). The dam also obstructs sediments that would naturally regenerate ecosystems downstream, so when the dam deprives the valley of its sediment load during runoff, it seeks to reabsorb it

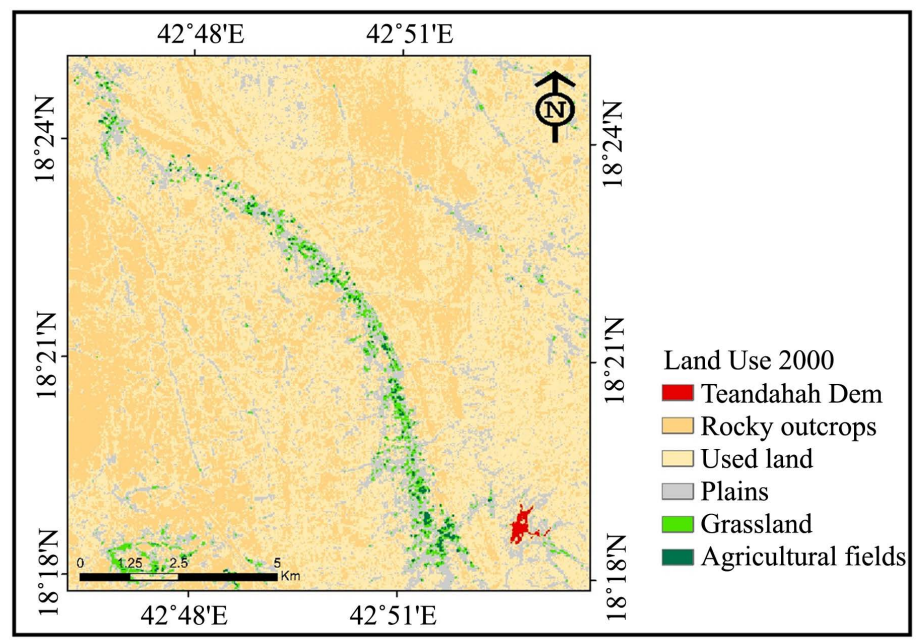

(a)

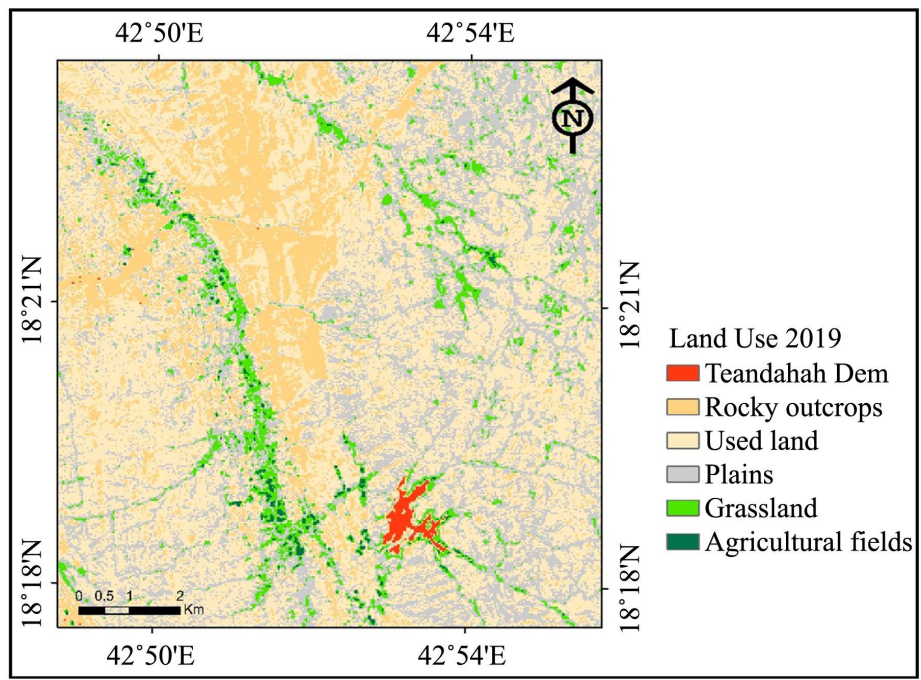

(b)

Figure 7. (a) Land use in the Tendahah region for the year 2000; (b) Land use in the Tendahah region for the year 2019. 
through erosion of the riverbed and the banks in the wadi bed (which can undermine the bridges and dam structures). The valley's streams are eroded directly at the beginning of the estuary, causing the emergence of trenches and the continuous carving of the estuary until the buried rocks emerged at a depth of meters as a result of the flow, in addition to forming water swamps at the downstream as a result of water drilling, which poses environmental and health problems for the residents near the dam. Another important and clear effect is the transformation of the upper dam from the lake's ecosystem into a loose water pool in the form of swamps that create a suitable environment for mosquitoes, as a result of changes in temperature, chemical composition, dissolved oxygen levels, and the physical properties of the lake, which are not suitable for plants and animals. These changes increase the chance of algae and snails forming, which in turn affect life inside the lake.

\subsection{Conclusion}

After conducting a careful field survey, and taking the opinions of many farmers in the study area, it can be concluded that due to poor water management in a run-down dam, farmers face major problems, which led to a decline in groundwater levels, especially the further away from the dam lake, this, in turn, was reflected in the agricultural fields, and also led to some farmers losing their farms. It also affected the flood soils that the valley brings during the runoff. The choice of the site for the construction of the Tendahah dam is inappropriate, as it was built in a base rocks area that does not allow water to be filtered into the ground layers, and the lack of periodic maintenance has led to the accumulation of silt or sediments over decades, which caused the creation of a waterproofing layer and did not allow it to filter For aquifer bearing layers. The study also showed that there is a large evaporation process of water in the dam reservoir, which is due to the high temperatures. The traditional irrigation methods that are active in the study area cause a big problem, from the salinization of the soil as a result of water immersion, to the waste of large quantities of water, and irrigation of the plant with more water than it needs.

\subsection{Recommendations}

This study recommends some points, the most important of which are:

1) Changing the irrigation systems in the study area, which is important to conserve water and soil, and expand the area of cultivation.

2) The dam cannot be removed, even if it is desired by many farmers, it limits floods due to the force of runoff with the presence of a slope of the valley course; But the dam can be better maintained and managed, and any attempt to remove old sediments to allow water to filter into the water-bearing layers.

3) Investing the dam lake by establishing irrigation channels and linking it to the dam lake, and allowing farmers to benefit from these channels, at inexpensive prices, which will positively reflect on farmers, and be an economic tributary for the investor, and benefit from the lake water instead of evaporation, and at 
the same time replenish the water in Lake dam.

4) Underground well water is sold without desalination, and this may cause problems in the case of human use; in the presence of desalinated water, it is easy to do without this water. Also, its use in public projects such as the construction of roads, buildings, industries, etc., can be replaced by treated water at the sewage station in Khamis Mushayt to replace the groundwater, and this requires a decision and firmness from the competent authorities.

\section{Conflicts of Interest}

The author declares no conflicts of interest regarding the publication of this paper.

\section{References}

Abushandi, E. (2016). Flood Prevention Dams for Arid Regions at a Micro-Scale Sub-Catchment, Case Study: Tabuk, Saudi Arabia. Water Science and Technology, 74, 2523-2533. https://doi.org/10.2166/wst.2016.341

Ashraf, M., Kahlown, M. A., \& Ashfaq, A. (2007). Impact of Small Dams on Agriculture and Groundwater Development: A Case Study from Pakistan. Agricultural Water Management, 92, 90-98. https://doi.org/10.1016/j.agwat.2007.05.007

Çelik, R. (2018). Impact of Dams on Groundwater Static Water Level Changes: A Case Study Kralkızı and Dicle Dam Watershed. Uluslararası Mühendislik Araştırma ve Geliștirme Dergisi, 10, 119-126. https://doi.org/10.29137/umagd.442483

Ejaz, N., Naeem, U. A., Shahmim, M. A., Elahi, A., \& Khan, N. M. (2016). Environmental Impacts of Small Dams on Agriculture and Ground Water Development: A Case Study of Khanpur Dam, Pakistan. Pakistan Journal of Engineering and Applied Sciences, 10, 45-50.

Ibnlaboun, A. (2019). Asir Geological Features. Riyadh: Dar and Agency Ibnlaboun for Publication and Distribution.

Jaafar, H. H. (2014). Feasibility of Groundwater Recharge Dam Projects in Arid Environments. Journal of Hydrology, 512, 16-26. https://doi.org/10.1016/j.jhydrol.2014.02.054

McCully, P. (1996). Silenced Rivers: The Ecology and Politics of Large Dams. London: Zed Books.

Na, B. K., Kim, J. Y., Kwon, H. H., \& Lim, J. Y. (2014). Improvement of Hydrologic Dam Risk Analysis Model Considering Uncertainty of Hydrologic Analysis Process. Journal of Korea Water Resources Association, 47, 853-865. https://doi.org/10.3741/JKWRA.2014.47.10.853

Rosenberg, D. M., McCully, P., \& Pringle, C. M. (2000). Global-Scale Environmental Effects of Hydrological Alterations: Introduction. Bioscience, 50, 746-751. https://doi.org/10.1641/0006-3568(2000)050[0746:GSEEOH]2.0.CO;2

Rueda, F., Moreno-Ostos, E., \& Armengol, J. (2006). The Residence Time of River Water in Reservoirs. Ecological Modelling, 191, 260-274. https://doi.org/10.1016/j.ecolmodel.2005.04.030

Soares, S., Terêncio, D., Fernandes, L., Machado, J., \& Pacheco, F. A. (2019). The Potential of Small Dams for Conjunctive Water Management in Rural Municipalities. International Journal of Environmental Research and Public Health, 16, 1239. https://doi.org/10.3390/ijerph16071239 
Straskraba, M., Tundisi, J. G., \& Duncan, A. (1993). State-of-the-Art of Reservoir Limnology and Water Quality Management. In Comparative Reservoir Limnology and Water Quality Management (pp. 213-288). Dordrecht: Springer.

https://doi.org/10.1007/978-94-017-1096-1_13

Thobaity (2009). Final Report of Study and Design of Irrigation Project in Tendahah Dem. Jeddah: Ministry of Water and Electricity. General Management of Asir Region. Prepared by Thobaity Office for Water Engineering and Studies.

Zarfl, C., Lumsdon, A. E., Berlekamp, J., Tydecks, L., \& Tockner, K. (2014). A Global Boom in Hydropower Dam Construction. Aquatic Sciences, 77, 161-170.

https://doi.org/10.1007/s00027-014-0377-0 